\title{
EVALUATION OF BENIGN BREAST DISEASE IN RAMA MEDICAL COLLEGE HOSPITAL AND RESEARCH CENTRE
}

Govind Trivedi' ${ }^{1}$ Rajeev Bhargava ${ }^{2}$, Manukant Bhatnagar ${ }^{3}$

${ }_{1}^{1}$ Associate Professor, Department of General Surgery, Rama Medical College Hospital \& Research Centre, Mandhana, Kanpur. 2 Professor, Department of General Surgery. Rama Medical College Hospital \& Research Centre, Mandhana, Kanpur.

3Intern, Department of General Surgery. Rama Medical College Hospital \& Research Centre, Mandhana, Kanpur.

\section{ABSTRACT}

\section{BACKGROUND}

Benign breast disease includes a spectrum of lesions having a wide range of symptoms or may be detected as incidental finding on microscopic examination. The present study tries to classify and report the incidence of various benign breast diseases in relations to the key factors such as age, marital status, intake of oral contraceptives, menstrual cycle, pregnancy, lactation, socioeconomic status.

\section{MATERIALS AND METHODS}

The study was conducted on 153 female patients presenting with breast related problems. The patients were clinically examined and investigated and finally evaluated with reference to various key symptoms.

\section{RESULTS}

The major 'benign breast disease' in our study includes mastalgia, fibroadenoma and lactation-related inflammatory conditions. The pattern and incidence of these diseases had definite list of factors which affected it. For example- 1. Age of marriage. 2. Socioeconomic status. 3. Oral contraceptives.

\section{CONCLUSION}

Overall incidence of benign breast disease was $15.3 \%$. Cyclical mastalgia was the major disease followed by unilateral fibroadenoma. Third common presentation was painless nodularity.

\section{KEYWORDS}

Mastalgia, Fibroadenoma, Mastitis, Oral Contraceptives, Benign Breast Disease (BBD).

HOW TO CITE THIS ARTICLE: Trivedi G, Bhargava R, Bhatnagar M. Evaluation of benign breast disease in Rama Medical College Hospital and Research Centre. J. Evolution Med. Dent. Sci. 2017;6(58):4313-4315, DOI: 10.14260/Jemds/2017/932

\section{BACKGROUND}

Breast is a dynamic organ involving a lot of morphological changes from menarche to menopause under the influence of hormones. The term "Benign Breast Disease" (BBD) encompasses a heterogeneous group of lesions that may present as a wide range of symptoms or it may be detected as incidental microscopic finding.

Up to $30 \%$ of females suffer from BBB in anytime of their life and this compels them to take the treatment. Early diagnosis and prompt treatment will alleviate patient's anxiety of having breast lump as carcinoma.

\section{Aims and Objectives}

The aim of this observational study is to see the patterns of benign breast disease, the mode of presentation and association with certain risk factors.

\section{MATERIALS AND METHODS}

The present observational study was conducted from November 2016 to May 2017 at Rama Medical College,

Financial or Other, Competing Interest: None.

Submission 14-05-2017, Peer Review 08-07-2017,

Acceptance 14-07-2017, Published 20-07-2017.

Corresponding Author:

Dr. Govind Trivedi,

Flat 206 A Block, Shiva Apartments,

Sarvoday Nagar, Kanpur- 208024.

E-mail: govind_trivedi03@yahoo.co.uk

DOI: $10.14260 /$ jemds $/ 2017 / 932$
Kanpur in Surgical OPD on female patients presenting with complaints related to breast. The patients with any obvious cancer, biopsy proven, elsewhere treated or operated for malignant disease were excluded from this study.

Assessment included detailed history about symptoms and their duration, menstrual patterns, pregnancy, lactation, OCP intake. Followed by clinical examination and use of imaging technique such as USG and mammography, histopathological confirmation was done with FNAC, core needle biopsy and excision biopsy. Patients were followed up throughout the entire course of diagnosis and management.

\section{RESULTS}

The observations were tabulated to reach the conclusions and they were compared with other contemporary studies.

The patients were broadly divided into 3 groups according to chief presenting complaints-

1. Mastalgia: Cyclical \& noncyclical with nodularity.

2. Fibroadenoma \& Painless nodularity.

3. Miscellaneous: Breast abscess and other inflammatory conditions; galactocoele; traumatic fat necrosis; Phyllodes tumours; Mondor's disease; nipple discharge.

Total 153 Female Patients Attending the Surgical OPD were Observed According to the Following Protocol:

1. Particulars of patient.

2. Chief complaints.

3. Obstetric and gynaecological history.

4. Medical history. 
5. Family history.

6. Clinical breast examination.

7. Investigation.

An observational study was conducted and the important relevant observations have been tabulated accordingly in following tables.

\begin{tabular}{|c|c|}
\hline Total no. of patients observed & 1000 \\
\hline No. of patients with benign breast disease & 153 \\
\hline Incidence & $15.3 \%$ \\
\hline
\end{tabular}

\begin{tabular}{|l|c|c|}
\hline Diagnosis & No. of Patients & Percentage (\%) \\
\hline Mastalgia & 91 & 57.96 \\
• Cyclical & 58 & 67.74 \\
Associated nodularity & 16 & 27.6 \\
- Noncyclical & 33 & 36.26 \\
- Associated nodularity & 7 & 21.21 \\
\hline Painless nodularity & 24 & 13.38 \\
\hline Fibroadenoma & 25 & 15.92 \\
\hline Breast abscess & 11 & 7.0 \\
\hline Miscellaneous & & \\
- Cyst & 2 & 1.27 \\
- Tubercular abscess & 2 & 1.27 \\
- Galactocoele & 2 & 1.27 \\
- Traumatic fat necrosis & 1 & 2.6 \\
- Phyllodes tumour & 1 & 0.6 \\
- Mondor's disease & 1 & 0.6 \\
\hline \multicolumn{2}{|c|}{ Table 2. Frequency of Benign Breast Diseases } \\
\hline \multicolumn{2}{|c|}{} \\
\hline
\end{tabular}

\begin{tabular}{|c|c|c|c|c|c|c|}
\hline \multirow{2}{*}{$\begin{array}{c}\text { Age Range } \\
\text { (Years) }\end{array}$} & \multicolumn{2}{|c|}{ Mastalgia } & \multirow{2}{*}{$\begin{array}{c}\text { Painless } \\
\text { Nodularity }\end{array}$} & Fibroadenoma & $\begin{array}{c}\text { Breast } \\
\text { Abscess }\end{array}$ & Miscellaneous \\
\hline$<20$ & 03 & 1 & 2 & 2 & 1 & 1 \\
\hline $21-30$ & 14 & 3 & 8 & 14 & 2 & 2 \\
\hline $31-40$ & 32 & 17 & 10 & 8 & 5 & 3 \\
\hline $41-50$ & 09 & 9 & 1 & 1 & 3 & 1 \\
\hline $51-60$ & - & 3 & - & - & - & 2 \\
\hline \multicolumn{7}{|r|}{ Nable 3. Age range of Patients } \\
\hline
\end{tabular}

Majority of patients were in 31-40 years age group $(47.8 \%)$. However, fibroadenoma was more common in 2130 years age group.

\begin{tabular}{|c|c|c|c|}
\hline Symptoms & Right & Left & Bilateral \\
\hline Pain & & & \\
Cyclical & 12 & 15 & 31 \\
Noncyclical & 20 & 24 & 07 \\
\hline Lump & 10 & 15 & 02 \\
\hline Nodularity & 4 & 5 & 14 \\
Painful & 5 & 3 & 13 \\
Painless & 12 & - & - \\
\hline Fever & 2 & 5 & 1 \\
\hline Nipple Discharge & 1 & - & - \\
\hline Trauma & \multicolumn{5}{|l}{} \\
\hline Table 4. Clinical Manifestations \\
\hline
\end{tabular}

\begin{tabular}{|c|c|c|c|c|c|}
\hline Diagnosis & Upper & $\begin{array}{c}\text { Upper } \\
\text { Middle }\end{array}$ & $\begin{array}{c}\text { Lower } \\
\text { Middle }\end{array}$ & $\begin{array}{c}\text { Upper } \\
\text { Middle }\end{array}$ & Lower \\
\hline Mastalgia & 3 & 5 & 45 & 27 & 11 \\
\hline $\begin{array}{c}\text { Painless } \\
\text { nodularity }\end{array}$ & 1 & 2 & 11 & 6 & 1 \\
\hline Fibroadenoma & 1 & 3 & 12 & 6 & 3 \\
\hline Breast abscess & - & - & 02 & 5 & 4 \\
\hline Miscellaneous & - & 2 & 2 & 4 & 1 \\
\hline
\end{tabular}

Table 5. Distribution based on Socioeconomic Status

Majority of patients (45.8\%) belonged to lower middle class.

\begin{tabular}{|c|c|c|}
\hline Diagnosis & Premenopausal & Postmenopausal \\
\hline Mastalgia & 81 & 10 \\
\hline Painless nodularity & 20 & 01 \\
\hline Fibroadenoma & 25 & - \\
\hline Breast abscess & 11 & - \\
\hline Miscellaneous & 7 & 2 \\
\hline \multicolumn{2}{|c|}{ Table 6. Distribution based on Menstrual Status } \\
\hline
\end{tabular}

89\% patients with mastalgia were premenopausal while 95.2\% with painless nodularity and all patients with fibroadenoma were premenopausal.

\begin{tabular}{|c|c|c|}
\hline Diagnosis & Taking OCP & Not Taking OCP \\
\hline Mastalgia & 53 & 38 \\
\hline Painless nodularity & 13 & 08 \\
\hline Fibroadenoma & 11 & 14 \\
\hline Breast abscess & 4 & 7 \\
\hline Miscellaneous & 2 & 7 \\
\hline \multicolumn{2}{|c|}{ Table 7. Relation to Oral Contraceptive Use } \\
\hline
\end{tabular}

$58.2 \%$ patients with mastalgia were taking OCP.

\section{DISCUSSION}

The present study conducted on 153 female patients having benign breast disease covered the rural as well as urban population in and around Kanpur. Study has shown that the majority of patients presenting to the OPD have benign diseases. Santen RJ [1].

The study is consistent with the study at Kings College Hospital Breast Clinic (London),[2] which shows that benign breast diseases are at least 10 times more common than breast cancer. [3], [4]

Many demographic and social factors such as age, [5], early marriage; socioeconomic status; menstrual status; oral contraceptives[6]; shyness; reluctance for breast examination, etc. contributed to the pattern of disease and availability of material.

The most frequent complaint of the patients was pain with lump (Mastalgia with nodularity) followed by pain alone.[7]

In present study, cyclical and non-cyclical mastalgia were present in $67.74 \%$ \& $36.26 \%$ respectively. Krishnaswamy[8] reported mastalgia as a major complaint [56.9\%]. Khanna AK et al[9] reported similar findings as cyclical mastalgia [61.5\%] to be more common than non-cyclical mastalgia [38\%]. 
Peak incidence of cyclical mastalgia is noted in the $3^{\text {rd }}$ decade of life.

An interesting correlation of oral contraceptive is noted with mastalgia [58.2\%] due to higher content of oestrogen. [6]

In a case study of benign breast disease in Boston University in 1986, fibroadenoma was found to be the commonest benign tumour during $2^{\text {nd }}$ decade of life in married nullipara.[10]

However, in our study, fibroadenoma was the $2^{\text {nd }}$ common benign breast disease [13.38\%] with more probability on left side. The age group was consistent with other studies.

Miscellaneous group included breast abscesses (7\%); tubercular abscesses (1.2\%); galactocoele (1.2\%); phyllodes tumour (0.6\%). [11], [12].

The results are consistent with studies of Rangabashyam[13] and Khanna. ${ }^{[9]}$

There were 7 patients with nipple discharge [4\%] in this study which goes parallel with the Krishnaswamy's study ${ }^{[8]}$ which reported $6.8 \%$.

\section{CONCLUSION}

We conclude from this study that benign breast diseases are more common than their malignant counterparts (10:1).

Cyclical nodular mastalgia is the commonest benign breast disease $(67.74 \%)$ with peak incidence in $3^{\text {rd }}$ decade, followed by fibroadenoma (15.9\%) with peak incidence in $2^{\text {nd }}$ decade.

Miscellaneous category ranks third in the study including inflammatory conditions and breast abscesses which had a definite correlation with pregnancy and lactation. FNAC was the most effective investigation, followed by USG and mammography.

However, the role of clinical examination cannot be overlooked.

But since in our study the sample size is small, much work needs to be done to collect comprehensive data for better understanding of the nature of benign breast disease and their proper management.

In Indian scenario, education regarding breast selfexamination and proper followup is highly recommended so that early treatment is sought.

\section{REFERENCES}

[1] Santen RJ, Mansel R. Benign breast disorders. N Engl J Med 2005;353(3):275-85.

[2] Hartmann LC, Sellers TA, Frost MH, et al. Benign breast disease and risk of breast cancer. $\mathrm{N}$ Engl J Med 2005;353(3):229-37.

[3] Collins LC, Baer HJ, Tamimi RM, et al. Magnitude and laterality of breast cancer risk in women with atypical hyperplasia of ductal and lobular types. Lab invest 2006;86(supple 1):24A.
[4] Onukak EE, Cederquist RA. Benign breast disorders in northwestern populations: part III- benign breast disorders in northern Nigeria. World J Surg 1989;13(6):750-2.

[5] Sterns EE. Age-related breast diagnosis. Can J Surg 1992;35(1):41-5.

[6] Rohan TE, Miller AB. A cohort study of oral contraceptive use and risk of benign breast disease. Int J Cancer 1999;82(2):191-6.

[7] Davies EL, Gateley CA, Miers M, et al. The long term course of mastalgia. J P Soc Med 1998;91(9):462-4.

[8] Krishnaswamy U. Profile of benign breast diseases in urban India. Indian Journal of Surgery 2003;65(2):178-81.

[9] Khanna R, Khanna S, Chaturvedi S, et al. Spectrum of breast disease in young females: a retrospective study of 1315 patients. Indian J Pathol Microbiot 1998;41(4):397-401.

[10] Franco N, Arnould L, Merge F, et al. Comparative analysis of molecular alterations in fibroadenomas associated or not with breast cancer. Arch Surg 2003;138(3):291-5.

[11] Chen WH, Cheng SP, Tzen CY, et al. Surgical treatment of phyllodes tumors of the breast: retrospective review of 172 cases. J Surg Oncol 2005;91(3):185-94.

[12] Reeves ME, Tabuenca A. Lactating adenoma presenting as a giant breast mass. Surgery 2000;127(5):586-8.

[13] Rangabashyam N, Gyanparkasham D, Krishnaraj B, et al. Spectrum of benign breast lesion. J Roy Surgeons Edinburgh 1983;28:369-73.

[14] Tavassoli FA, Norris HJ. A comparison of the results of long-term follow up for atypical intraductal hyperplasia and intraductal hyperplasia of the breast. Cancer 1990;65(3):518-29.

[15] Carter BA, Page DL, Schuyler P, et al. No elevation in long-term breast carcinoma risk for women with fibroadenomas that contain atypical hyperplasia. Cancer 2001;92(1):30-6.

[16] Chaudhuri M, Sen S, Sengupta J. Breast lumps: a study of 10 years. J Indian Med Assoc 1995;93(12):455-7.

[17] Shabtai M, Saavedra-Malinger P, Shabtai EL, et al. Fibroadenoma of the breast: analysis of associated pathological entities--a different risk marker in different age groups for concurrent breast cancer. Isr Med Assoc J 2001;3(11):813-7.

[18] Soo MS, Dash N, Bentley R, et al. Tubular adenomas of the breast: imaging findings with histologic correlation. AJR Am J Roentgenol 2000;174(3): 757-61 